\title{
Topset-to-forest rollover trajectories as reliable predictors of sediment-volume partitioning into deep-lake areas
}

\author{
Xian-Zheng Zhao ${ }^{1} \cdot$ Cheng-Lin Gong ${ }^{2,3} \cdot$ Li-Hong Zhou $^{1} \cdot$ Dong-Wei Li ${ }^{3} \cdot$ Xiu-Gang Pu ${ }^{1} \cdot$ Guo-Meng Han ${ }^{1}$. \\ Feng-Ming $\mathrm{Jin}^{1} \cdot$ Yi-Xin $\mathrm{Yu}^{2,3} \cdot$ Wen-Ya Jiang ${ }^{1} \cdot$ Xiong-Ying Dong ${ }^{1}$
}

Received: 17 August 2020 / Accepted: 8 December 2020 / Published online: 31 May 2021

(c) The Author(s) 2021

\begin{abstract}
Topset-to-forest rollover trajectories and their relation to sediment- and sand-budget partitioning into deep-lake areas are far from being well understood, as compared with their marine counterparts of shelf edges. Two quantitatively distinctive topset-to-forest rollover trajectories and clinothem-stacking patterns were recognized in the Oligocene Qikou Sag of the Bohai Bay Basin and are quantified in terms of trajectory angles $\left(T_{\mathrm{se}}\right)$, topset thickness $\left(T_{\mathrm{t}}\right)$, forest thickness $\left(T_{\mathrm{f}}\right)$, bottomset thickness $\left(T_{\mathrm{b}}\right)$, and clinothem-set relief $\left(R_{\mathrm{c}}\right)$. Rising topset-to-forest trajectories have positive $T_{\mathrm{se}}$ of $0.15^{\circ}-0.51^{\circ}$ (averaging $\left.0.35^{\circ}\right)$. Ranges in $T_{\mathrm{t}}, T_{\mathrm{f}}, T_{\mathrm{b}}$, and $R_{\mathrm{c}}$ of their associated progradational and aggradational clinothem sets are, respectively, 32.4-58.7 m (averaging 42.7 m), 76.9-176.2 m (averaging 148.3 m), 0 m, and 167.8-320.8 m (averaging $272.9 \mathrm{~m}$ ). Falling topset-to-forest rollover trajectories, in contrast, have negative $T_{\mathrm{se}}$ of $-0.12^{\circ}$ to $-0.02^{\circ}$ (averaging $-0.06^{\circ}$ ). Ranges in $T_{\mathrm{t}}$, $T_{\mathrm{f}}, T_{\mathrm{b}}$, and $R_{\mathrm{c}}$ of their associated progradational and downstepping clinothem sets are, respectively, $0 \mathrm{~m}, 266.0-395.7 \mathrm{~m}$ (averaging $333.4 \mathrm{~m}$ ), 441.1-542.5 m (averaging 464.1), and 874.9-922.6 m (averaging $892.5 \mathrm{~m}$ ). These two topset-to-forest rollover trajectories and clinothem-stacking patterns are closely linked to two distinctive patterns of sediment- and sandvolume partitioning into deep-lake areas, which are quantified in terms of $T_{\mathrm{t}}, T_{\mathrm{b}}$, and differential sediment aggradation of topset segments and forest-to-bottomset compartments $\left(A_{\mathrm{s}} / A_{\mathrm{d}}\right)$. Rising topset-to-forest rollover trajectories and associated progradational and aggradational clinothem sets are characterized by aggradational topsets (reported as $T_{\mathrm{t}}$ of $32.4-58.7 \mathrm{~m}$ ), a lack of time-equivalent bottomsets, and $A_{\mathrm{s}} / A_{\mathrm{d}}$ of $0.22-0.87$ (averaging 0.33 ), and are fronted by mud-dominated depositional deposits, with sporadic occurrence of thinner and regionally localized forest sands. They are, therefore, inefficient at delivering terrestrial sediments or sands into deep-lake settings. Falling topset-to-forest rollover trajectories and associated progradational and downstepping clinothem sets, in contrast, are characterized by toplap, erosional terminations but aggradational bottomsets (reported as $T_{\mathrm{b}}$ of 266.0-473.4 m), and $A_{\mathrm{s}} / A_{\mathrm{d}}$ of 0 , and are fronted by sand-rich depositional deposits, with widespread occurrence of thicker and regionally extensive time-equivalent deep-lake bottomset sands. They are, thus, efficient at delivering terrestrial sediments or sands into deep-lake settings. Topset-to-forest rollover trajectories and associated clinothem-stacking patterns are thus reliable predictors of sediment- and sand-volume partitioning into deep-lake areas, assisting greatly in developing a more dynamic stratigraphy.
\end{abstract}

Keywords Topset-to-forest rollover trajectories · Sediment-delivery paradigm · Oligocene Qikou Sag · Bohai Bay Basin

Edited by Jie Hao and Chun-Yan Tang

Cheng-Lin Gong

chenglingong@cup.edu.cn

1 PetroChina Dagang Oilfield Company, Tianjin 300280, China

2 State Key Laboratory of Petroleum Resources and Prospecting, China University of Petroleum (Beijing), Beijing 102249, China

3 College of Geosciences, China University of Petroleum (Beijing), Changping, Beijing 102249, China

\section{Introduction}

Trajectory analysis, a sequence stratigraphic tool originally developed by Helland-Hansen and Martinsen (1996) for describing shoreline movements, is considered as a significant advancement in the field of sequence stratigraphy and basin analysis (Catuneanu et al. 2009, 2011; HellandHansen and Hampson 2009; Henriksen et al. 2009; Gong et al. 2015). Shelf edges in marine basins are defined as an important zone of slope gradient changes, which separates 
a flat-lying shelf (i.e., topset domain) dominated by waves and shelf currents from the steeper slope (i.e., forest domain) and gentle basin-floor reaches (i.e., bottomset domain) dominated by sediment gravity-flow processes (i.e., HellandHansen and Hampson 2009; Henriksen et al. 2009; Wild et al. 2009; Jones et al. 2013; Laugier and Plink-Björklund 2016; Gong et al. 2019a). Topset-to-forest rollover points in lacustrine basins are defined as the gradient changes at the passages at the passage between topsets and forests (i.e., Patruno and Helland-Hansen 2018; Gamberi et al., 2020; Trincardi et al. 2020). The application of trajectory analysis to shelf edges and topset-to-forest rollover points results in two important concepts in sequence stratigraphy and basin analysis, namely shelf-edge trajectories (Helland-Hansen and Hampson, 2009) and topset-to-forest rollover trajectories (Sztanó et al. 2013; Patruno and Helland-Hansen 2018; Gong et al. 2019b). Shelf-edge trajectories in marine basins and topset-to-forest rollover trajectories in lacustrine basins describe the lateral and vertical migration of shelf edges and topset-to-forest rollover points without any preconception of the controls on their development and are key to reconstructing scenarios of accommodation and sediment supply (Catuneanu et al. 2009, 2011; Helland-Hansen and Hampson 2009; Gong et al. 2015, 2016; Cosgrove et al. 2018; Paumard et al. 2018, 2020). A comparison of flat shelf-edge trajectories versus flattish topset-to-forest rollover trajectories suggests that relatively thick versus thin or absent bottomsets occur in the marine and lacustrine settings, respectively (Sztanó et al. 2013; Gong et al. 2019b). In the past 20 year or so, concepts of shelf-edge trajectories have been widely used to investigate stratigraphy and sedimentology of deepwater siliciclastic systems in marine basins. They have been the subject of increasingly intense studies in recent years and have been proved to be useful predictors of the relative amounts of sediments or sands passed to deep-water areas, which constitute over $15 \%$ of siliciclastic hydrocarbon reservoirs and are important exploration targets worldwide (e.g., Helland-Hansen and Hampson 2009; Henriksen et al. 2009; Gong et al. 2016; Pellegrini et al. 2020). For example, flat to slightly falling shelf-edge trajectories are widely considered as the proxy for delivering significant volumes of coarse clastics into the deep sea (Gong et al. 2015, 2016; Cosgrove et al. 2018; Paumard et al. 2018; Pellegrini et al. 2017, 2020). Despite significant improvements in our understanding of marine shelf-edge trajectories and their relation to sand- and sediment-volume partitioning into deepwater, possible relationships between lacustrine topset-to-forest rollover trajectories and relative amounts of sediments and sands passed to deep-lake floors remain to be formulated and tested (e.g., Sztanó et al. 2013; Gong et al. 2019b).

The present study employs three-dimensional (3D) seismic, borehole, and acoustic impedance data from the Qikou Sag of the Bohai Bay Basin to: (1) quantify Oligocene topset-to-forest rollover trajectories and their associated clinothem-stacking patterns; (2) investigate sediment- and sand-budgets partitioning into deep-lake floors; (3) explore relationships between topset-to-forest rollover trajectories and relative amounts of sediments or sands passed to deeplake areas.

\section{Geological settings of the study area}

The study area of the present study is from the Qikou Sag of the Huanghua Depression, which is located in the central part of the Bohai Bay Basin (blue shaded box in Fig. 1a). Huanghua depression underwent a complex tectonic evolution during the Cenozoic, including the NWW-NNE extension caused by the mantle heat activity and the dextral strike slip induced by the NNE dextral strike-slip fracturing (Wang et al. 2003; Li et al. 2009; Huang et al. 2008, 2012). It is bounded to the east by the Shaleitian uplift, to the west by the Cangxian uplift, to the north by the Yanshan fold belt, and to the south by the Chenning uplift (Fig. 1b). It is elongated and parallel to the Cangdong fault in the axial direction (Fig. 1b). Qikou Sag is composed of Chenbei step-fault belts, Qikou main sag, and four main Sub-sags (i.e., Beitang, Banqian, Qibei, and Qinan Sub-sags), thereby showing a complex paleogeomorphology (Figs. 1, 2) (e.g., Huang et al. 2012; Feng et al. 2016). Trajectories of topset-to-forest rollover points and their relation to the delivery of terrestrial sediments and sands into deep-water bottomsets of the Qibei Sub-sag of the Huanghua Depression is the focus of the present study. Qibei Sub-sag is a half graben and is bounded by the Qikou main sag to the east, by the Yangsanmu Uplift to the west, by the Binhai fault to the north, and by the Nandagang fault to the south (Figs. 1,2).

Tectonically, the Qikou Sub-sag underwent two main tectonic evolutionary stages, including a Paleogene rifting stage and a Neogene to Quaternary post-rifting stage (e.g., Huang et al. 2012; Feng et al. 2016) (Fig. 2). Paleogene syn-rift and Neogene to Quaternary post-rift stages, respectively, experienced a high tectonic subsidence rate of up to $300 \mathrm{~m} / \mathrm{Ma}$ and a low tectonic subsidence rate of down to less than $40 \mathrm{~m} / \mathrm{Ma}$ (Huang et al. 2012). Accordingly, the fill of the Qikou Subsag can be divided into two main supersequences, including a syn-rift and post-rift supersequences (e.g., Huang et al. 2012; Jiang and Liu 2015) (Fig. 3). Paleocene synrift supersequence is composed of Shahejie and Dongying Formations, and is bounded at its base by the basin-wide unconformity of T6 dated at $42 \mathrm{Ma}$ (e.g., Huang et al. 2012; Jiang and Liu 2015) (Fig. 3). Neogene to Quaternary postrift supersequence consist of Guantao and Minghuazhen Formations and is bounded at its base by the basin-wide unconformity of T2 dated at $24 \mathrm{Ma}$ (e.g., Huang et al. 2012; Jiang and Liu 2015; Feng et al. 2016; Jiang et al. 2020) 


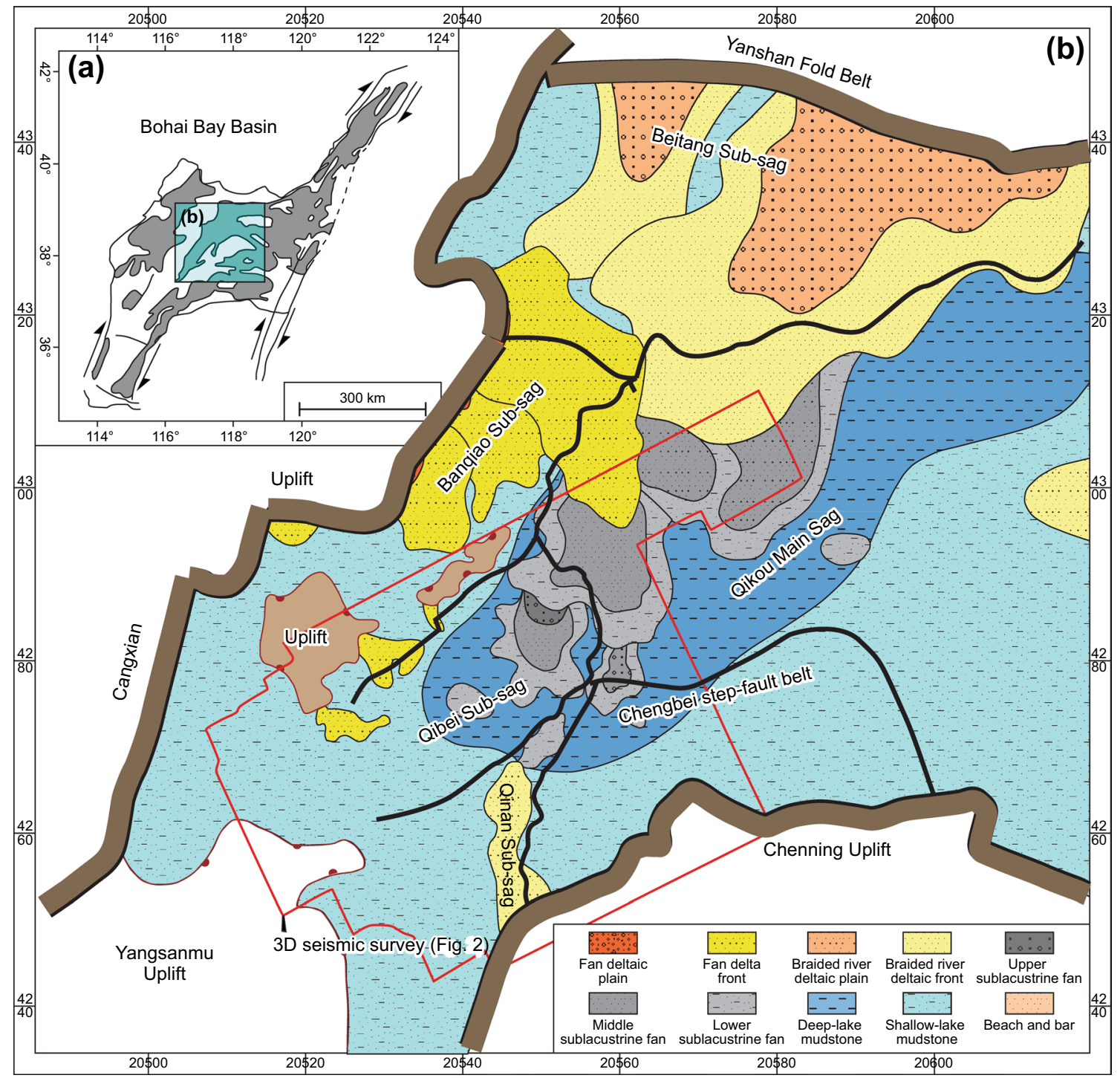

Fig. 1 a Schematic map showing the geographical location and context of the study areas of the present research (i.e., the Qikou Sag of the Huanghua Depression). b Schematic maps showing tectonostratigraphic features of the Qikou Sag of the Huanghua Depression and major depositional facies developed during the deposition of $\mathrm{Ed}_{2}{ }^{\text {nd }}$ Member of the Dongying Formation

(Fig. 3). Paleogene and Neogene successions of the Qikou Sub-sag can be divided into four second-order and 17 thirdorder sequences (e.g., Wu et al. 2010; Huang et al. 2012; Jiang et al. 2020) (Fig. 3). Oligocene Dongying Formation in the Qikou Sub-sag is composed of four $3^{\text {rd }}$ order sequences, namely $\mathrm{SQEd}_{3}, \mathrm{SQEd}_{2}, \mathrm{SQEd}_{1}{ }^{\mathrm{L}}$, and $\mathrm{SQEd}_{1}{ }^{\mathrm{U}}$ (Jiang and Liu 2015) (Fig. 3). Seismically well-imaged topset-to-forest rollover trajectories and their associated clinothem sets were developed within $\mathrm{SQEd}_{2}$ (i.e., $\mathrm{Ed}_{2}{ }^{\text {nd }} \mathrm{Member}$ of the Dongying Formation) and $\mathrm{SQEd}_{1}{ }^{\mathrm{L}}$ (i.e., the lower part of the 1st Member of the Dongying Formation) (Figs. 3, 4, 5). These topset-to-forest rollover trajectories, clinothem sets, and their relation to sediment- and sand-budget partitioning into deep-lake floors are the focus of the present study.

\section{Database and methodology}

\subsection{D seismic reflection data}

The primary datasets utilized in the present study are 3500 $\mathrm{km}^{2}$ 3D seismic data, tied to borehole information (see Fig. 2 for a perspective view of the 3D seismic cube), both of which were acquired and provided by the PetroChina Dagang Oilfield from the Qikou Sag. 3D seismic data used in this study (polygon with red outline in Fig. 1b) have a bin size spacing of $25 \mathrm{~m}$ (in-line) by $25 \mathrm{~m}$ (cross-line) and a sampling interval of $4 \mathrm{~ms}$. They have been processed using the pre-stack hybrid migration algorithm and have a dominant frequency of $15-30 \mathrm{~Hz}$, yielding a vertical resolution of 16.6-33.3 m 


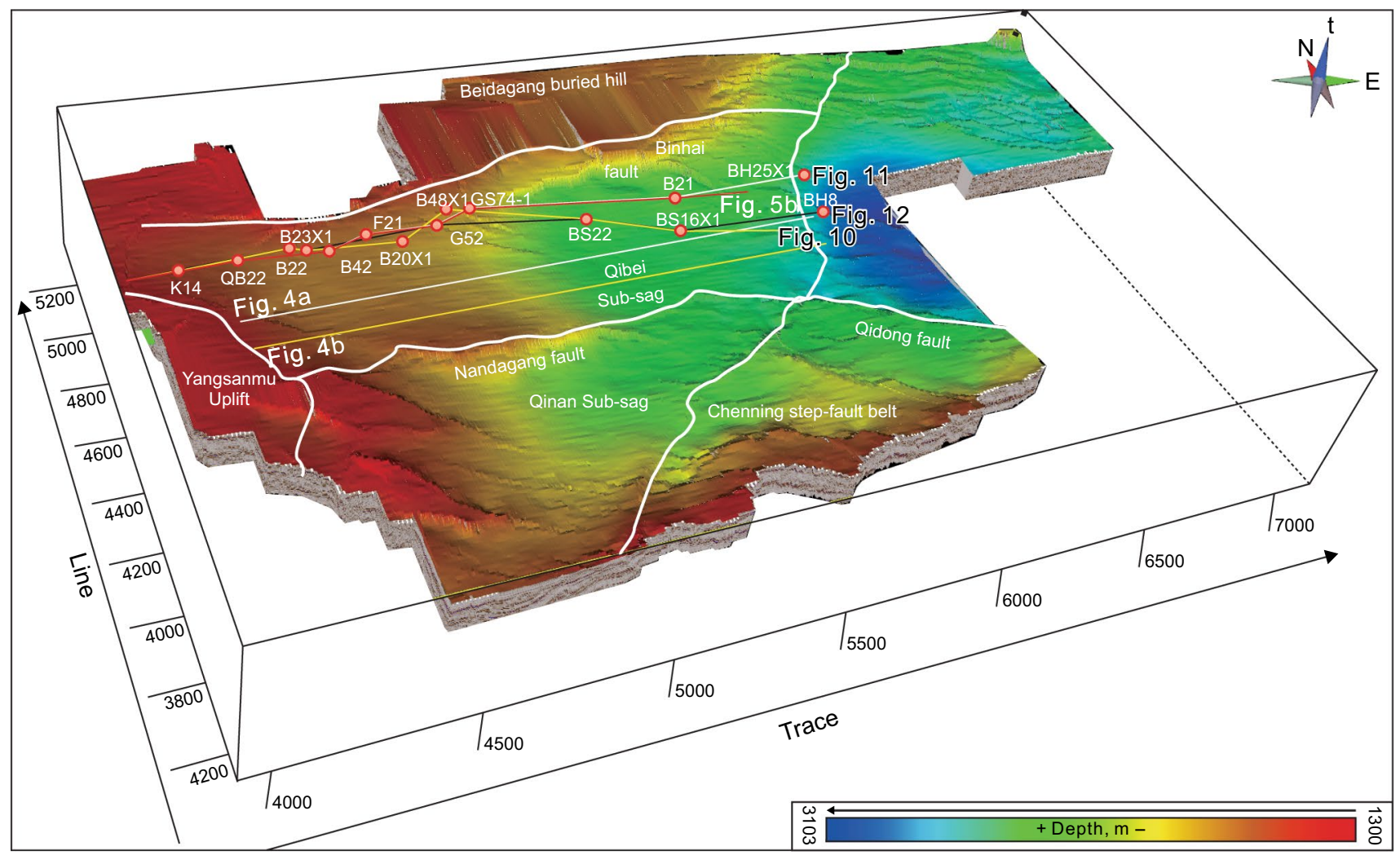

Fig. 2 3D perspective view of the structure map of the basal bounding surface of the $\mathrm{Ed}_{2}{ }^{\text {nd }}$ Member of the Dongying Formation draped on seismic volume utilized in this study showing the main tectonostratigraphic features of the study area. Also shown are regional map-view locations of wells, seismic transects shown in Figs. 4 and 5, acoustic impedance profile of Fig. 10, and well-log stratigraphic correlation sections presented in Figs. 11 and 12

( $\lambda / 4)$ and a detection limit of 2.6-5.3 m ( $\lambda / 25)$. 3D seismic data were displayed using SEG negative standard polarity, where a positive reflection coefficient corresponds to an increase in acoustic impedance and is represented by a positive reflection event. They are displayed using a red-whiteblack color bar, where the low-impedance reservoir top is displayed as a peak (black in color). 3D seismic data were tied to 13 wells (see Fig. 2 for their map-view locations), each of which has lithologies, biostratigraphy data, and high-quality well-logging curves, including gamma ray (GR), acoustic (AC), spontaneous-potential (SP), and density.

Post-stack seismic inversion is the use of the acoustic information from seismic data such as the velocity, impedance, and amplitude to extract geological information of subsurface layers such as lithology, density, porosity, compaction, etc. (Pendrel 2006). This method yields more accurate interpretations of the lithology distribution and can be employed to predict lithological properties away from the well control (Pendrel 2006). The sonic and density logs, check shots, and formation markers obtained from wells K14, QB22, B22, B23X1, B42, F21, G52, GS74-1, BS22, $\mathrm{BS} 16 \mathrm{X} 1, \mathrm{~B} 21, \mathrm{BH} 8$, and BH25X1 (see their map-view locations in Fig. 2), together with a 2D seismic transect cross these eight wells, were carefully processed and used for the post-stack seismic inversion. Well-log data were also utilized for seismic-well tie and age constraints, after which ages and geological significance of key seismic reflection surfaces and seismic facies recognized in the Qibei Sub-sag were determined.

\subsection{Seismic interpretation and quantification}

Topset-to-forest rollover points are defined as an important zone of gradient changes which separates a flat-lying topset domain dominated by river or deltaic processes from the steep slope forest domain and gentle basin-floor bottomset domain dominated collectively by gravitydriven processes. Topset-to-forest rollover trajectories were mapped and determined by linking successive topset-to-forest rollover points as indicated by colored dots in Figs. 4, 5 and 6. Similar to shelf edges, topset-toforest rollover points were recognized and picked on seismic lines on the basis of two main principles, namely a significant gradient increasing and a significant clinothem thickening (Helland-Hansenn and Hampson 2009; Henriksen et al. 2009; Laugier and Plink-Björklund 2016). 


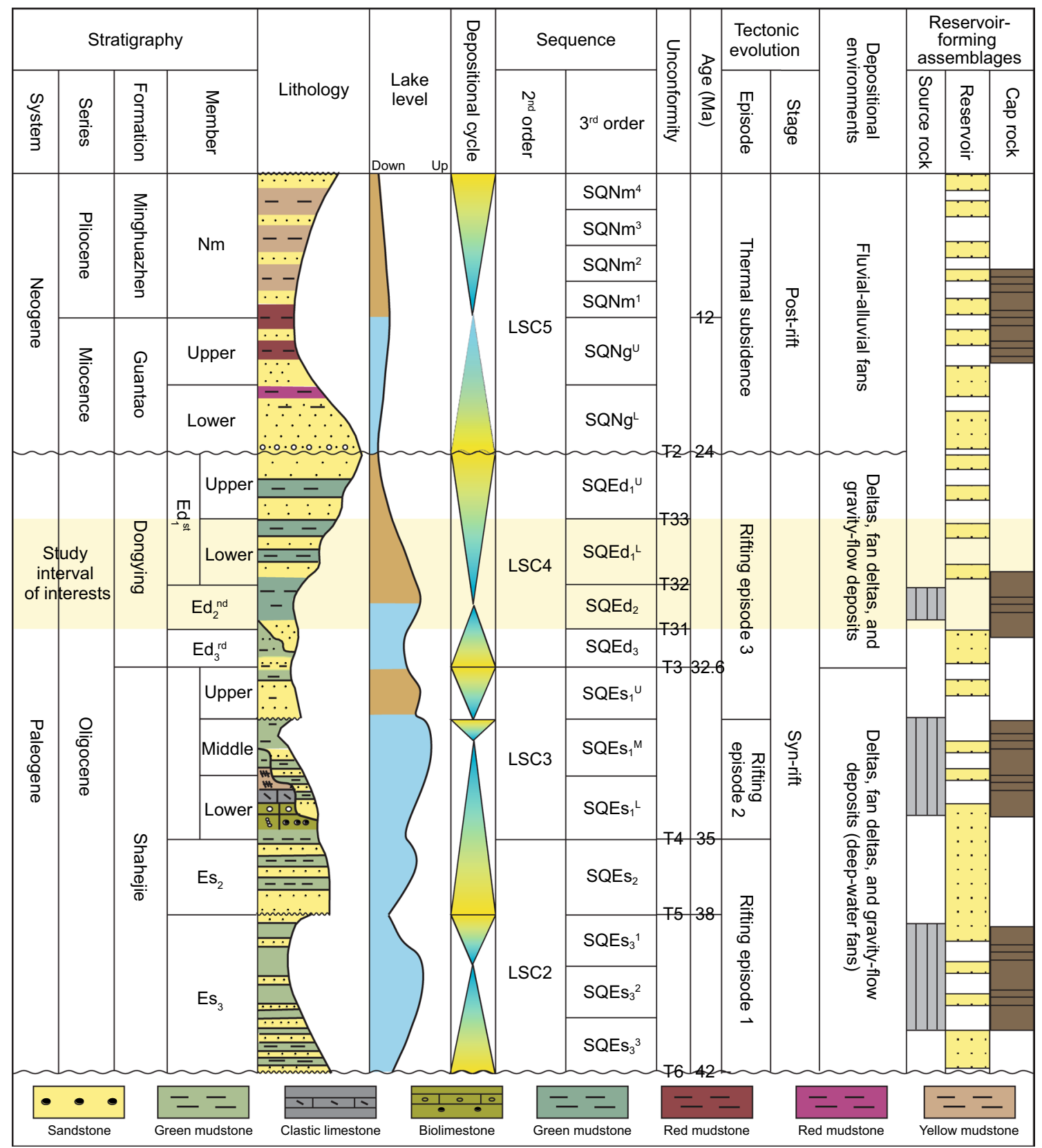

Fig. 3 The lithological and sequence stratigraphic chart of the Qikou Sag in the Huanghua Depression of the Bohai Bay Basin (partly compiled from Jiang et al., 2020). Note that $\mathrm{SQEd}_{2}$ (i.e., $\mathrm{Ed}_{2}{ }^{\text {nd }} \mathrm{Member}$ of the Dongying Formation) and $\mathrm{SQEd}{ }_{1}^{\mathrm{L}}$ (i.e., the lower part of the $1 \mathrm{st}$ Member of the Dongying Formation) are the study interval of interest of the present study

The restoration of the palaeo-horizontal surfaces in the Qikou Sub-sag was implemented to remove the post-Oligocene deformation and differential compaction-related subsidence by flattening the utilized seismic cube to the basin-wide unconformity of T2 dated at 24 Ma (Figs. 4, 5). Oligocene Qikou topset-to-forest rollover trajectories and their associated clinothem sets are quantified by their trajectory angles $\left(T_{\mathrm{se}}\right)$ and clinothem-set reliefs $\left(R_{\mathrm{c}}\right)$.
$T_{\mathrm{se}}=\arctan \left(\frac{\mathrm{d} y}{\mathrm{~d} x}\right)$

where $\mathrm{d} x$ is the forward rollover-point progradation and $\mathrm{d} y$ is the vertical rollover-point aggradation. $R_{\mathrm{c}}$ is reported as a single value, as measured from a distance of $5 \mathrm{~km}$ from the respective topset-to-forest rollover point. The latter method of $R_{\mathrm{c}}$ is similar to that used by Pyles et al. (2011) to quantitatively compare different types of regional stacking 


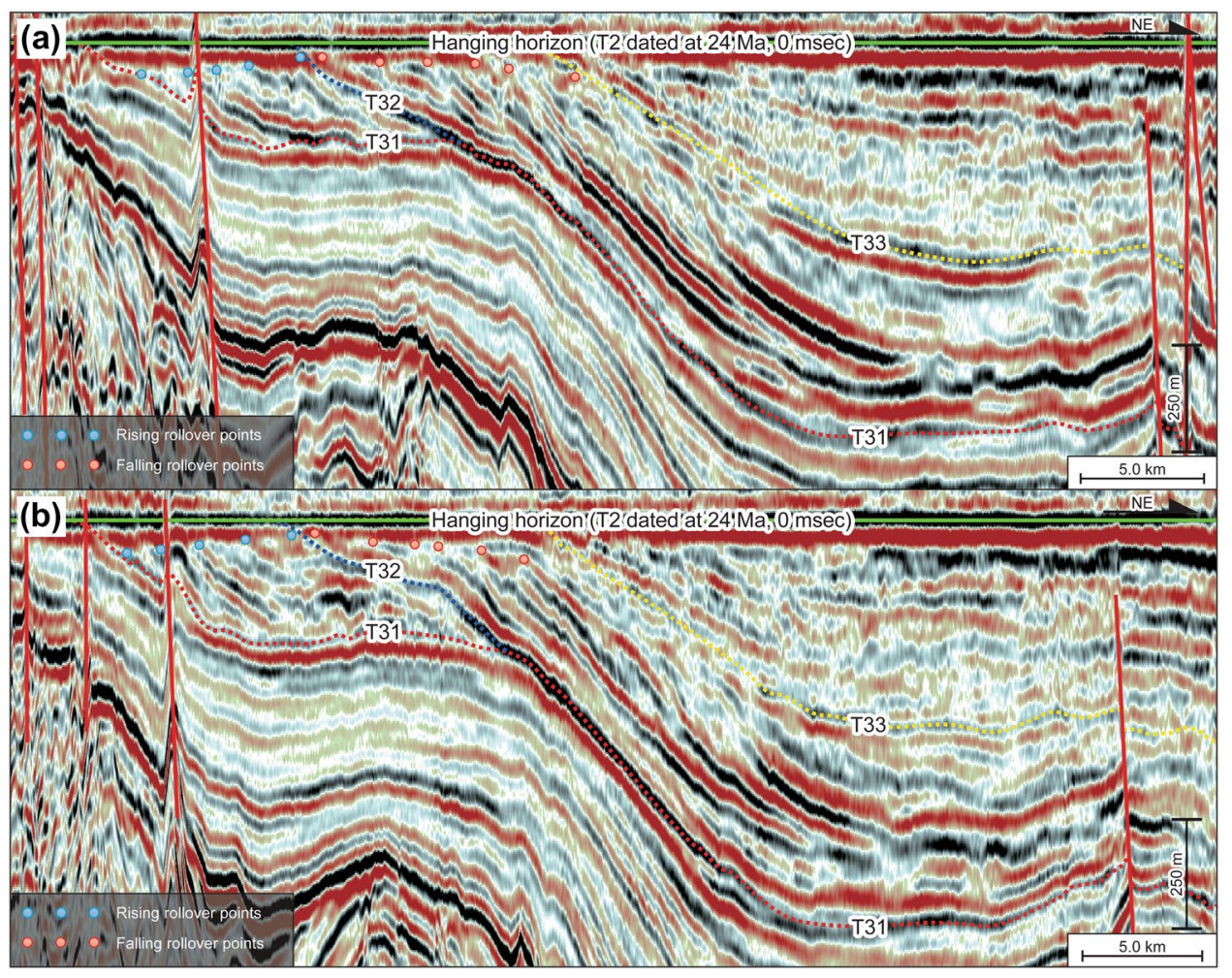

Fig. 4 Depositional dip-oriented seismic transects from the Qibei Sub-sag (see Fig. 2 for regional map-view locations) showing the occurrence of two phases of topset-to-forest rollover-point growth. The shown seismic lines were flattened by the unconformity of T2 dated at $24 \mathrm{Ma}$, in order to restore paleohorizontals and original patterns of the documented topset-to-forest rollover trajectories

patterns and to that employed by Villamil et al. (1998) to relate paleongological patterns to longitudinal profiles in northern Gulf of Mexico.

The relative amounts of terrestrial sands passed to deeplake floors can be roughly estimated by thicknesses and distributions of sandy deposits developed on bottomsets of individual clinothem sets. Three main important rules are employed in this study to quantify relative amounts of terrestrial sediments passed to deep-lake floors. Stratal terminations (i.e., topset, toplap, and downlap terminations) are symptomatic of sediment- and sand-budget partitioning into deep-lake floors. Depositional topsets are suggestive of the storage of great volumes of clastic detritus onto topsets, with little volumes of terrestrial sediments passed to lakefloor bottomsets, whereas erosional toplap and bottomset downlap terminations are indicative of the delivery of great volumes of clastic detritus into lake-floor bottomsets, with little volumes of terrestrial sediments delivered onto topsets (Gong et al. 2015, 2016; Cosgrove et al. 2018; Paumard et al. 2018, 2020, among others). Secondly, the relative volume of clastic detritus delivered onto shallow-water topset compartments of individual clinothem sets can be roughly estimated by topset thickness of individual clinothem sets $\left(T_{\mathrm{t}}\right)$, while relative volume of clastic detritus passed to deep-water compartments of individual clinothem sets can be roughly quantified by forest and bottomset thicknesses of individual clinothem sets ( $T_{c}$ and $T_{\mathrm{b}}$, respectively) (e.g., Gong et al. 2015; Paumard et al. 2018; Liu et al. 2020). Thirdly, the relative volume of clastic detritus delivered onto shallow-water topset and deep-water compartments of individual clinothem sets can be roughly estimated by the differential sediment aggradation of topset segments and forest-to-bottomset deep-lake compartments $\left(A_{\mathrm{s}} / A_{\mathrm{d}}\right) . A_{\mathrm{s}} / A_{\mathrm{d}}$, a measure developed herein denotes the ratio between the amounts of terrestrial sediments delivered on the topsets $\left(A_{\mathrm{s}}\right)$ (i.e., shallow-water sedimentation) to that of forests and bottomsets $\left(A_{\mathrm{d}}\right)$ (i.e., deep-water sedimentation). Smaller $A_{\mathrm{s}} / A_{\mathrm{d}}$ values refer to the domination of forest and bottomset (deepwater) deposition, whereas higher $A_{\mathrm{s}} / A_{\mathrm{d}}$ values refer to the domination of shallow-water topset deposition (see also Gong et al. 2015; Paumard et al. 2018).

\section{Quantification of Qibei topset-to-forest rollover trajectories}

The studied lacustrine successions are divided into two phases that record the sequential evolution of the Dongying Formation in the Qibei Sub-sag (i.e., $\mathrm{SQEd}_{2}$ and 

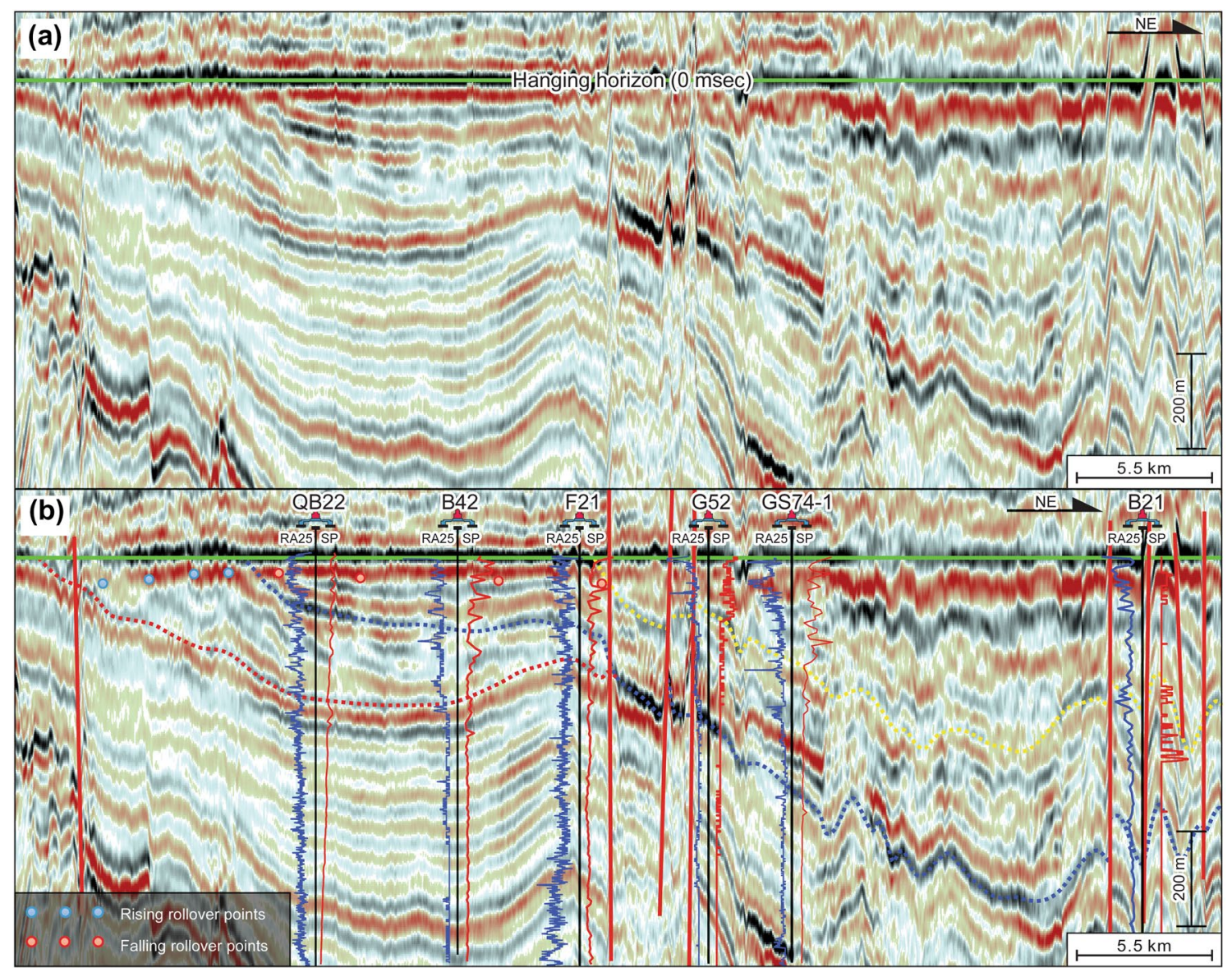

Fig. 5 Depositional dip-oriented seismic-well tie transect (see Fig. 2 for regional map-view location) showing the calibration between basal and upper bounding surfaces of the documented Qibei topset-to-forest rollover trajectories and wells K14, B22, B23X1, B20X1, B48X1, Bs22, and BS16X1. The shown seismic lines were flattened by the unconformity of $\mathrm{T} 2$ dated at $24 \mathrm{Ma}$, in order to restore paleohorizontals and original patterns of the documented topset-to-forest rollover trajectories
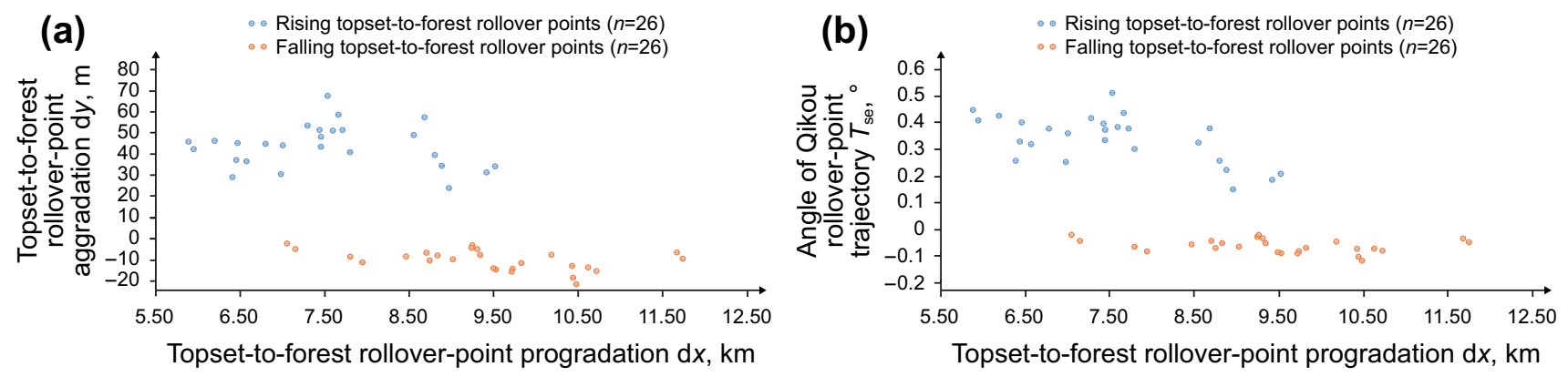

Fig. 6 Scatterplots of $\mathrm{d} x$ against $\mathrm{d} y$ and $\mathrm{d} x$ against $T_{\text {se }}$ (upper and lower panels, respectively)

$\mathrm{SQEd}_{1}{ }^{\mathrm{L}}$ ), each of which contains quantitatively and graphically distinctive topset-to-forest rollover trajectories and clinothem-set stacking patterns, as discussed below.

\subsection{Phase I: rising topset-to-forest rollover trajectories}

The first population of topset-to-forest rollover points contains rollover points that display an overall slightly rising trajectory tendency (Figs. 4, 5), referred to herein as slightly 
rising topset-to-forest rollover trajectories. Slightly rising topset-to-forest rollover points are indicated by blue dots in Figs. 4 and 5. Figure 6a and b suggests that this population of topset-to-forest rollover points to be statistically distinctive from the second population of topset-to-forest rollover points as described below. Ranges in $\mathrm{d} x, \mathrm{~d} y$, and $T_{\mathrm{se}}$ of slightly rising topset-to-forest rollover trajectories are, respectively, 23.9-67.4 m (averaging $45 \mathrm{~m}$ ), 5.8-9.5 km (averaging $7.6 \mathrm{~km}$ ), and $0.15^{\circ}-0.51^{\circ}$ (averaging $0.35^{\circ}$ ), respectively (blue dots in Fig. 6a and b). Slightly rising topset-to-forest rollover trajectories were also reorganized in the late Miocene Pannon Lake (Sztanó et al. 2013; Gong et al. 2019b), suggesting that they may be a common phenomenon in lacustrine basins worldwide (Figs. 4, 5, 7).

\subsection{Phase II: falling topset-to-forest rollover trajectories}

The second population of topset-to-forest rollover growth contains rollover points that display an overall slightly falling trajectory trend (Figs. 4, 5), referred to herein as slightly falling topset-to-forest rollover trajectories. Slightly falling topset-to-forest rollover points are indicated by orange dots in Figs. 2, 3 and 4. Figure 6a and $b$ suggests that this population of topset-to-forest rollover points to be statistically distinctive from slightly rising topset-to-forest rollover points as described above. Ranges in $\mathrm{d} x, \mathrm{~d} y$, and $T_{\mathrm{se}}$ of slightly falling topset-to-forest rollover trajectories are, respectively, -2.2 to $-21.4 \mathrm{~m}$ (averaging $-10.2 \mathrm{~m}$ ), 7.1-11.7 $\mathrm{km}$ (averaging $9.4 \mathrm{~km}$ ), and $-0.12^{\circ}$ to $-0.02^{\circ}$ (averaging $-0.06^{\circ}$ ), respectively (orange dots in Fig. 6a, b). Slightly falling topsetto-forest rollover trajectories were also reorganized in the late Miocene Pannon Lake (Sztanó et al. 2013; Gong et al. 2019b), suggesting that they may be a common phenomenon in lacustrine basins worldwide (Figs. 4, 5, 7).

\section{Quantification of Qibei clinothem-stacking patterns}

Each of the above two regimes of topset-to-forest rollover trajectories records a specific clinothem-stacking pattern (represented by $T_{\mathrm{t}}, T_{\mathrm{f}}, T_{\mathrm{b}}, R_{\mathrm{c}}$, and $A_{\mathrm{s}} / A_{\mathrm{d}}$ ) as discussed below (Figs. 8, 9).

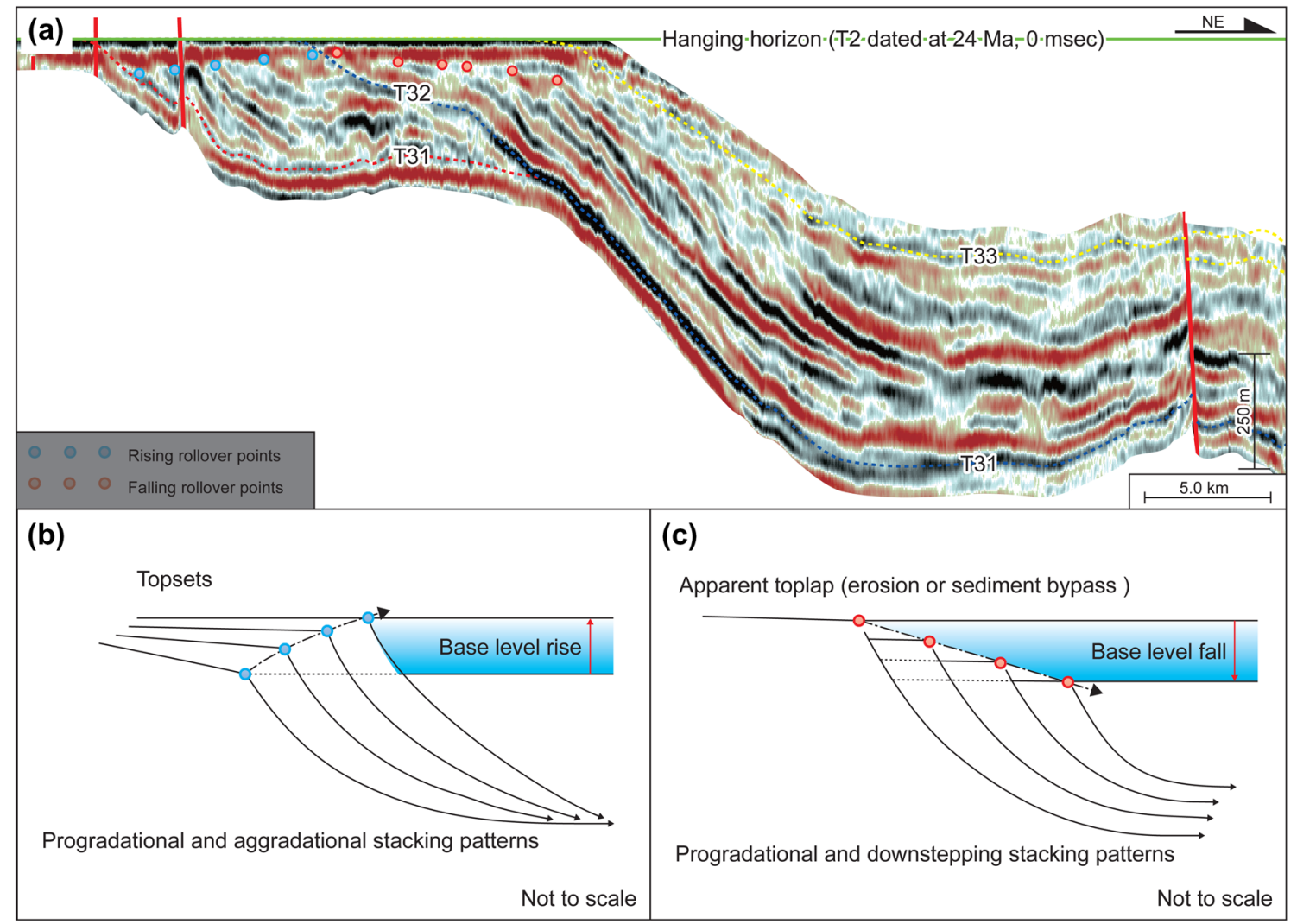

Fig. 7 Dip-oriented seismic transect and its accompanying line drawings deciphering architectural styles and growth patterns of the documented topset-to-forest rollover points and associated clinothem sets. Please refer to the section titled "quantification of Qibei topset-to-forest rollover trajectories" for the difference in kinematics of rising and falling topset-to-forest rollover trajectories. To illustrate architectural styles and growth patterns of clinothem sets rather than their geometries, panels $\mathbf{b}$ and $\mathbf{c}$ of this figure are not to scale 


\subsection{Phase I: progradational and aggradational clinothem sets}

Clinothem sets in the chronologically older phase of the study interval of interests are characterized by the lower $R_{\mathrm{c}}$ and a lack of time-equivalent bottomsets (Fig. 8a) and are accompanied by slightly rising topset-to-forest rollover trajectories (Figs. 4, 5, 7a). Architecturally, they display a combination of progradational and aggradational stacking patterns (Figs. 4, 5, 7a, b), referred to herein as progradational and aggradational clinothem sets. Progradational and aggradational clinothem sets are made up of successive sigmoidal progradational packages that exhibit a parallelism of upper stratal segments (topsets) [reported as $T_{\mathrm{t}}$ of 32.4-58.7 m (averaging $42.7 \mathrm{~m}$ ) and $T_{\mathrm{f}}$ of 76.9-176.2 m (averaging 148.3 m)] (Figs. 4, 5, 7a, $\mathrm{b}, 8 \mathrm{a})$. They are dramatically different from their progradational and downstepping counterparts by a lack of regionally extensive aggradational bottomsets (reported as $T_{\mathrm{b}}=0$ ) (Figs. 4, 5, 7a, b). Seismic-well tie verifies that progradational and aggradational clinothem sets are bounded at their base and top, respectively, by unconformities of T31 and T32 (Figs. 4, 5, 7a). They were, therefore, developed during the deposition of the $\mathrm{Ed}_{2}{ }^{\text {nd }}$ Member of Oligocene Dongying Formation (Fig. 3). Ranges in $R_{\mathrm{c}}$ and
$A_{s} / A_{\mathrm{d}}$ of progradational and aggradational clinothem sets are, respectively, 167.8-320.8 $\mathrm{m}$ (averaging 272.9) and 0.22-0.48 m (averaging 0.30) (Fig. 9a, b).

\subsection{Phase II: progradational and downstepping clinothem sets}

Clinothem sets in chronologically younger phase of the study interval of interests are accompanied by slightly falling topset-to-forest rollover trajectories (Figs. 4, 5, 7a). Architecturally, they prograded and downstepped in the basinward direction, displaying a diagnostic progradational and downstepping stacking pattern, referred to herein as progradational and downstepping clinothem sets (Figs. 4, $5,7 \mathrm{a}, \mathrm{b})$. Progradational and downstepping clinothem sets are characterized by oblique progradational clinoforms that show toplap, erosional terminations at their uppermost level in the proximal reaches (reported as $T_{\mathrm{t}}=0$ ), but sigmoidal clinoforms with very strong aggradation in the distal reaches [reported as $T_{\mathrm{f}}$ of $266.0-395.7 \mathrm{~m}$ (averaging $333.4 \mathrm{~m}$ ) and $T_{\mathrm{b}}$ of 441.1-542.5 m (averaging 464.1 m)] (Figs. 4, 5, 7a, b, 8a). They are dramatically different from their progradational and aggradational counterparts by the occurrence of regionally extensive aggradational bottomsets that can be traced for $10 \mathrm{~s} \mathrm{~km}$ throughout the Qibei Sub-sag (Figs. 4,
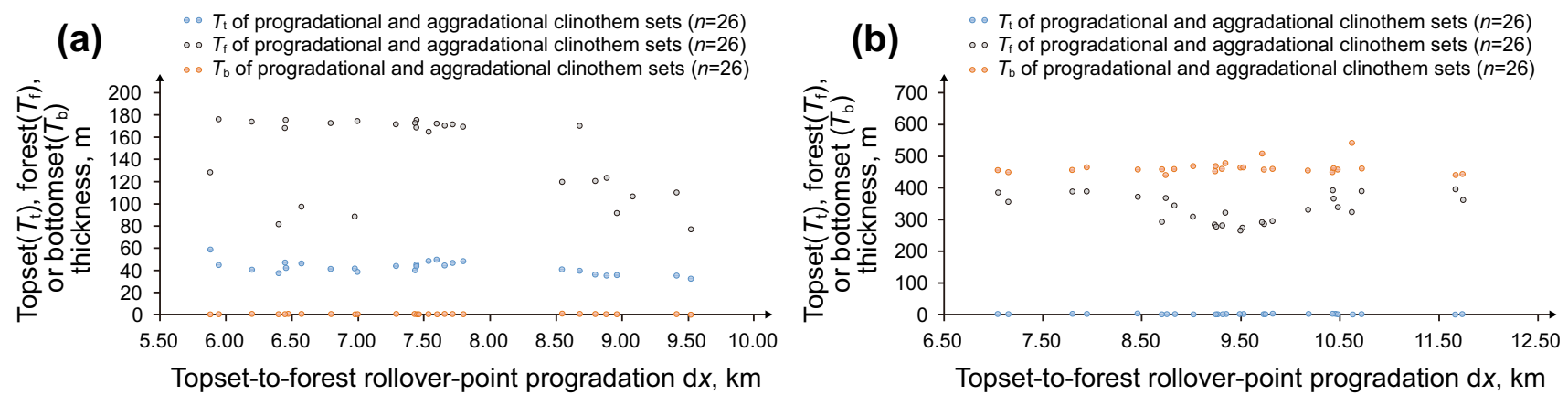

Fig. 8 Scatterplots of $\mathrm{d} x$ versus $T_{\mathrm{t}}$ and $\mathrm{d} x$ versus $T_{\mathrm{b}}$ (upper and lower panels, respectively)
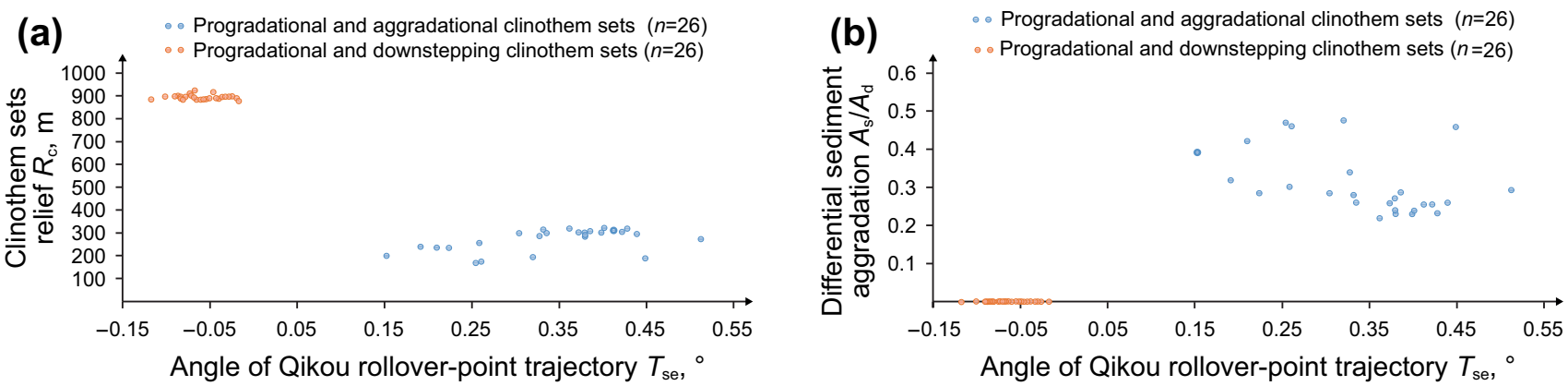

Fig. 9 Scatterplots of $T_{\mathrm{se}}$ against $R_{\mathrm{c}}$ and $T_{\mathrm{se}}$ against $A_{\mathrm{s}} / A_{\mathrm{d}}$ (upper and lower panels, respectively) 
$5,7 \mathrm{a}, \mathrm{b})$. Seismic-well tie verifies that progradational and downstepping clinothem sets are bounded at their base and top, respectively, by unconformities of T32 and T33 (Figs. 4, 5, 7a). Progradational and downstepping clinothem sets were, therefore, developed during the deposition of the lower part of $\mathrm{Ed}_{1}{ }^{\text {st }}$ Member of Oligocene Dongying Formation (Fig. 3). Ranges in $R_{\mathrm{c}}$ and $A_{\mathrm{s}} / A_{\mathrm{d}}$ of progradational and downstepping clinothem sets are, respectively, 874.89-922.6 m (averaging 892.5) and 0 (Fig. 9a, b).

\section{Relationships between topset-to-forest rollover trajectories and sediment-volume partitioning into deep-lake areas}

The sediment-volume partitioning referred to herein involves the relative amounts of terrestrial sediments passed to deeplake floors (represented by $T_{\mathrm{t}}, T_{\mathrm{b}}$ and $A_{\mathrm{s}} / A_{\mathrm{d}}$ ).

\subsection{Rising topset-to-forest rollover trajectories implying little amounts of sediments passed to deep-lake areas}

The chronologically older phase of topset-to-forest rollover growth is characterized by the higher values of $T_{\mathrm{t}}$ of 32.4-58.7 m, with mean value of $42.7 \mathrm{~m}$ and a standard deviation of $\pm 5.6 \mathrm{~m}$ and by the higher values of $A_{\mathrm{s}} / A_{\mathrm{d}}$ ranging from $0.22-0.87$, with mean value of 0.33 and a standard deviation of \pm 0.15 (Figs. 8a, 9b), as compared with falling topset-to-forest rollover trajectories. $T_{\mathrm{t}}$ and $A_{\mathrm{s}} / A_{\mathrm{d}}$ of progradational and aggradational clinothem sets with slightly rising topset-to-forest rollover trajectories are much higher than those of progradational and downstepping clinothem sets. These observations, coupled with the fact that no seismically resolvable bottomsets are seen to occur in front of slightly rising topset-to-forest rollover trajectories (reported as $T_{\mathrm{b}}=0$ ) (Figs. 4, 5, 7a, b, 8a), strongly suggest that the storage of the bulk of the sediment-budget storage on the topset compartments of individual progradational and aggradational clinothem sets, without much bypass to deep-lake areas beyond rollover points. It is, therefore, likely that slightly rising topset-to-forest rollover trajectories imply the delivery of very limited or no volumes of sediments into deep-lake floors.

\subsection{Falling topset-to-forest rollover trajectories implying significant amounts of sediments passed to deep-lake areas}

The chronologically younger phase of topset-to-forest rollover growth is characterized by higher values of $T_{\mathrm{f}}$ of 441.1-542.5 m, with mean value of $464.1 \mathrm{~m}$ and a standard deviation of $\pm 20.2 \mathrm{~m}$ and by higher values of $T_{\mathrm{b}}$ of 266.0-473.4 m, with mean value of $352.6 \mathrm{~m}$ and a standard deviation of $\pm 67.8 \mathrm{~m}$ (Fig. 8b). $T_{\mathrm{f}}$ and $T_{\mathrm{b}}$ of progradational and downstepping clinothem sets with slightly falling topsetto-forest rollover trajectories are much higher than those of progradational and aggradational clinothem sets, strongly suggesting that the delivery of significant volumes of terrestrial sediments into deep-lake areas (Gong et al. 2015; Paumard et al. 2018; Liu et al. 2020). The occurrence of aggradational bottomsets in front of falling topset-to-forest rollover trajectories suggests that sediment erosion, bypass, and resultant delivery to deep-water areas are predominant during this phase of topset-to-forest rollover growth (Figs. 4, 5, 7a, c) (see also Catuneanu et al. 2009, 2011; Gong et al. 2015). These observations, coupled with the fact that strongly aggradational bottomsets are seen to occur in front of slightly falling topset-to-forest rollover trajectories (reported as $T_{\mathrm{b}}$ of 441.1-542.5 m, with a mean value of $T_{\mathrm{b}}=464.1 \mathrm{~m}$ ) (Fig. $8 \mathrm{~b}$ ), suggest that the most of the sediment volumes supplied to the documented clinothem sets were eventually partitioned down to deep-water areas by progradational and downstepping clinothem sets with falling topset-to-forest rollover trajectories. It is, therefore, likely that slightly falling topset-to-forest rollover trajectories imply near total bypass of sediment volumes to deeplake areas, with very limited topset storage of terrestrial sediments.

\section{Relationships between topset-to-forest rollover trajectories and sand-budget partitioning into deep-lake areas}

The sand-budget partitioning referred to herein involves the relative amounts of terrestrial sands passed to deep-lake floors (represented by the thickness and distribution of sandy deposits developed in front of the documented topset-toforest rollover trajectories).

\subsection{Rising topset-to-forest rollover trajectories appear to be inefficient at delivering terrestrial sands into deep-lake areas}

Two lines of observations listed herein suggest that slightly rising topset-to-forest rollover trajectories are closed linked downdip to mud-dominated depositional deposits, with sporadic occurrence of sandy deposits, and are thus inefficient at delivering terrestrial sands into deep-lake settings (Figs. 10, 11, 12). Firstly, acoustic impedance section of Fig. 10 illustrates that progradational and aggradational clinothem sets with slightly rising topset-to-forest rollover trajectories are fronted by successions with low acoustic impedance, cool colors (i.e., blue and green), which are suggestive of 
mud-dominated properties. Secondly, log-stratigraphic correlation and composite sections of Figs. 11 and 12 show that sandy deposits occurring in front of slightly rising topset-toforest rollover trajectories (i.e., light gray, fine-grained sandstones, and light gray siltstones) are localized and sporadic, with thickness ranging from 1 to $10 \mathrm{~m}$ (averaging 2-4 m). This conclusion is in accord with conclusions reached by Gong et al. (2015), Pellegrini et al. (2017), and Paumard et al. (2018), who have collectively suggested rising shelfedge trajectories with aggradational topsets are inefficient at delivering coarse-grained terrestrial sands into deep-lake areas.

\subsection{Falling topset-to-forest rollover trajectories are most efficient at delivering terrestrial sands into deep-lake areas}

Three lines of observations from the current database suggest that slightly falling topset-to-forest rollover trajectories are accompanied by sand-rich depositional deposits, with widespread occurrence of sandy deposits occurring in front of them, and are therefore most efficient at partitioning coarsegrained clastic detritus into deep-lake areas (Figs. 10, 11, 12).
Firstly, progradational and downstepping clinothem sets with slightly falling topset-to-forest rollover trajectories are imaged themselves on the acoustic impedance section of Fig. 10 as oblique, hot-color accumulations (i.e., yellow and red) denote high acoustic impedance values (i.e., indicative of sand-prone deposits). Secondly, sandy deposits occurring in front of successions bounded by T32 and T33 are composed of light gray, gray-white, or gray fine-grained sandstones with thickness of 2-15 m (averaging 4-5 m) and gray siltstones with thickness of 1-8 m (averaging 4-5 m) (Figs. 11, 12). As compared with localized and sporadic sandy deposits developed in front of slightly rising topset-to-forest rollover trajectories, they are regionally extensive and widespread (Figs. 11, 12). It is, therefore, likely that slightly falling topset-to-forest trajectories allowed significant volumes of terrestrial sands passed to deep-lake areas. This hypothesis is consistent with conclusions reached by Gong et al. (2015), Pellegrini et al. (2017), and Paumard et al. (2018), who have collectively suggested falling shelf-edge trajectories with aggradational bottomsets are efficient at delivering coarse-grained detritus into deep-water reaches of strongly progradational shelf-margin clinothem sets with descending shelf-edge trajectories.

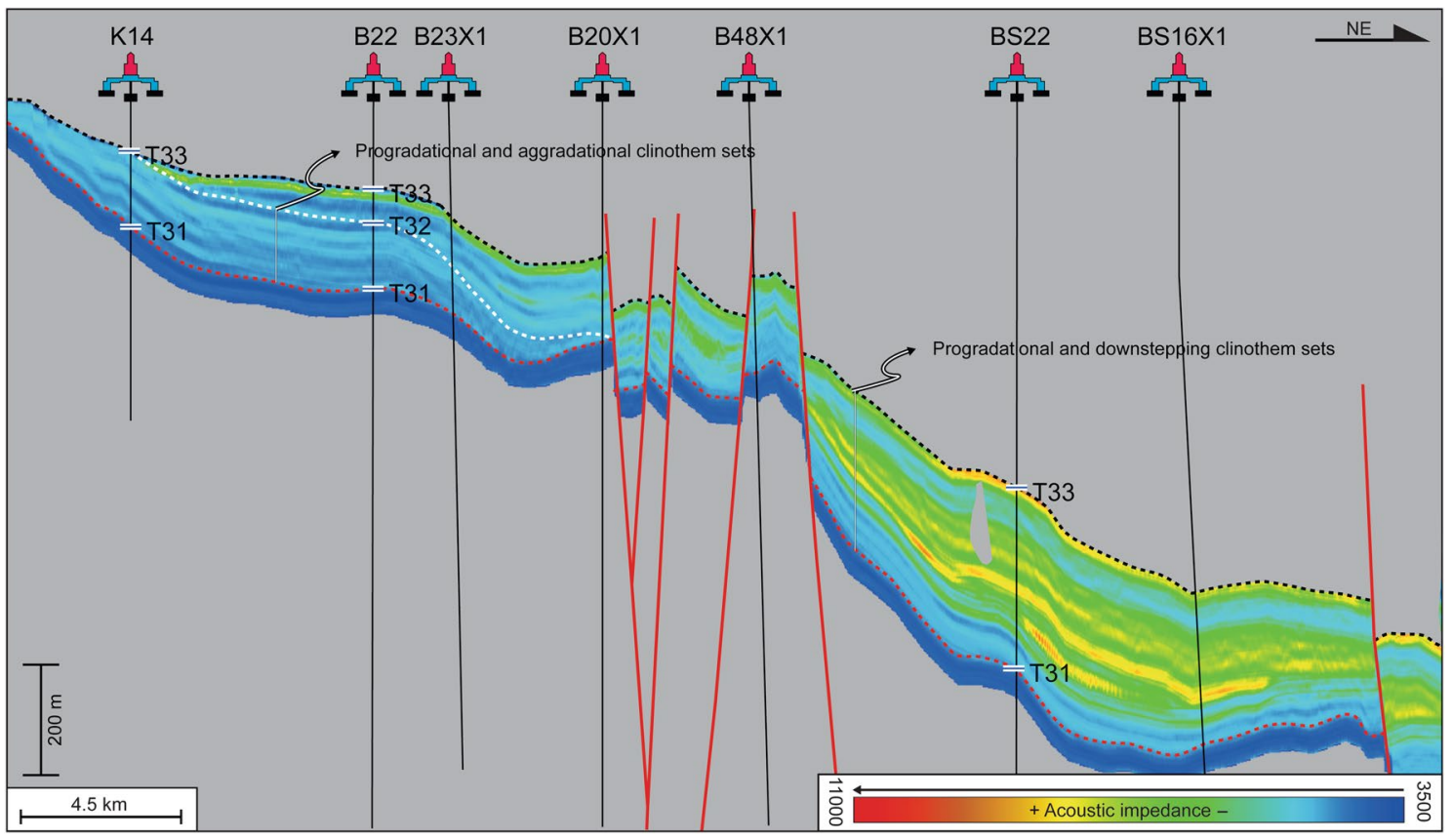

Fig. 10 Acoustic impedance section across wells K14, B22, B23X1, B20X1, B48X1, BS22, and BS16X1 (see Fig. 2 for map-view locations of the shown cross section and wells). Hot (yellow and orange) and cool (green and blue) colors represent sandy and muddy deposits, respectively 


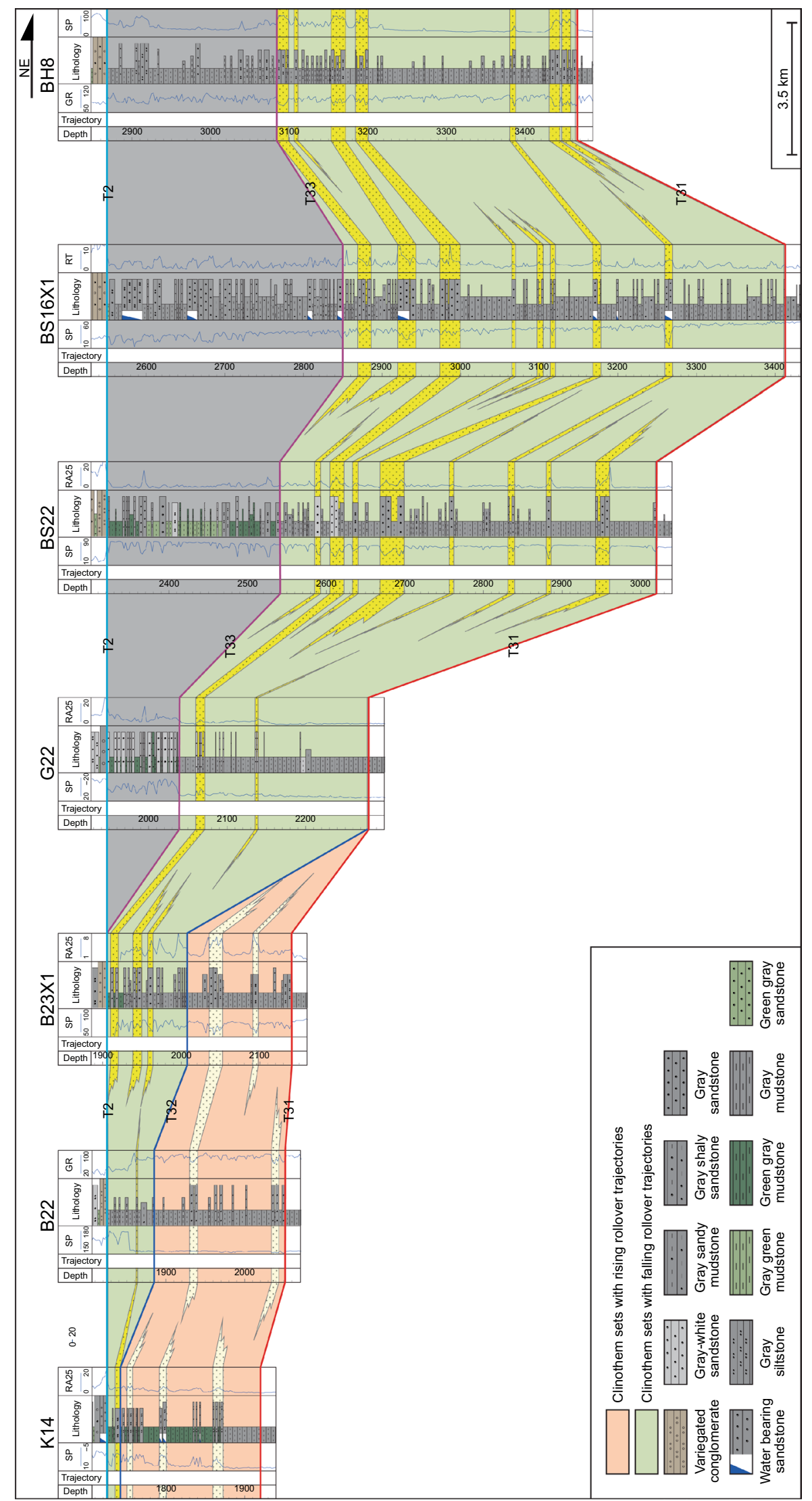


4Fig. 11 Log-stratigraphic correlation and composite section across wells K14, B22, B23X1, G22, BS22, BS16X1, and BH8 (see Fig. 2 for map-view locations of the shown cross section and wells). Note that sandy deposits occurring in younger succession bounded by T33 and T32 (i.e., progradational and downstepping clinothem sets with slightly falling topset-to-forest rollover trajectories) are much thicker and laterally more extensive than those bounded by T32 and T31 (i.e., progradational and aggradational clinothem sets with slightly rising topset-to-forest rollover trajectories)

\section{Topset-to-forest rollover trajectories as useful predictors of sediment- and sand-volume partitioning into deep-lake areas}

Slightly falling topset-to-forest rollover trajectories with positive $T_{\mathrm{se}}$ of $0.15^{\circ}-0.51^{\circ}$ (averaging $0.35^{\circ}$ ) lack time-equivalent bottomsets or deep-lake sandy deposits, and tend to be inefficient at delivering terrestrial sediments and sands into deep-lake areas, thereby holding little or no potential for the occurrence of coarse-grained, deep-lake sands on deep-lake floors (Figs. 4, 5, 10, 11, 12). Slightly falling topset-to-forest rollover trajectories with negative $T_{\mathrm{se}}$ of $-0.12^{\circ}$ to $-0.02^{\circ}$ (averaging $-0.06^{\circ}$ ) are linked to thicker and more extensive time-equivalent bottomsets or deep-lake sandy facies and appear to be efficient at transporting terrestrial sediments and sands into deep-lake areas, and thereby holding great potential for the presence of coarse-grained, deep-lake sands on deep-lake floors (Figs. 4, 5, 10, 11, 12). $T_{\text {se }}$, under the same sediment-supply conditions, tend to decrease linearly with sand- and sediment-budget partitioning into deep-lake settings and the potential for the presence of coarse-grained, lake-floor sands. Topset-to-forest rollover trajectories are, therefore, important for understanding sand distribution and sediment-routing systems and for predicting the presence of deep-lake sands. Observations and results from the current study contribute the establishment of a predictive relationship between topset-to-forest rollover trajectories and relative amounts of terrestrial sediments and sands passed to deep-lake areas, helping to predict the occurrence of sandrich deposits in deep-lake areas.

\section{Conclusions}

This study uses new and existing metrics to quantify aspects of topset-to-forest rollover trajectories $\left(T_{\mathrm{se}}\right)$, and associated clinothem-stacking patterns $\left(T_{\mathrm{t}}, T_{\mathrm{f}}, T_{\mathrm{b}}\right.$, and $\left.R_{\mathrm{c}}\right)$, and differential sediment aggradation of topset segments and forest-tobottomset compartments $\left(A_{\mathrm{s}} / A_{\mathrm{d}}\right)$. This study has shown that topset-to-forest rollover trajectories in lacustrine basins are useful but underappreciated predictors of relative amounts of terrestrial sediments and sands passed to deep-lake areas.

Two quantitatively distinctive topset-to-forest rollover trajectories and clinothem-stacking patterns were recognized: (1) slightly rising topset-to-forest rollover trajectories with $T_{\text {se }}$ of $0.15^{\circ}-0.51^{\circ}$ (averaging $0.35^{\circ}$ ) and associated progradational and aggradational clinothem sets with $T_{\mathrm{t}}$ of 32.4-58.7 m (averaging $42.7 \mathrm{~m}$ ), $T_{\mathrm{f}}$ of $76.9-176.2 \mathrm{~m}$ (averaging $148.3 \mathrm{~m}$ ), $T_{\mathrm{b}}$ of $0 \mathrm{~m}$, and $R_{\mathrm{c}}$ of $167.8-320.8 \mathrm{~m}$ (averaging $272.9 \mathrm{~m}$ ); and (2) slightly falling topset-to-forest rollover trajectories with $T_{\mathrm{se}}$ of $-0.12^{\circ}$ to $-0.02^{\circ}$ (averaging $-0.06^{\circ}$ ) and associated progradational and aggradational clinothem sets with $T_{\mathrm{t}}$ of $0 \mathrm{~m}, T_{\mathrm{f}}$ of $266.0-395.7 \mathrm{~m}$ (averaging $333.4 \mathrm{~m}$ ), $T_{\mathrm{b}}$ of $441.1-542.5 \mathrm{~m}$ (averaging 464.1), and $R_{\mathrm{c}}$ of $874.9-922.6 \mathrm{~m}$ (averaging $892.5 \mathrm{~m}$ ).

Each of the above two regimes of topset-to-forest rollover trajectories and associated lake-scale clinothem-stacking patterns are empirically related to distinctive styles of sediment- and sand-volume partitioning into deep-lake areas. Rising topset-to-forest rollover trajectories with positive $T_{\mathrm{se}}$ have high values of $A_{\mathrm{s}} / A_{\mathrm{d}}$ of $0.22-0.87$ (averaging 0.33 ) and are fronted by a lack of time-equivalent bottomsets and by mud-dominated forests, with sporadic occurrence of thinner and regionally localized sandy deposits. They are, thus, inefficient at delivering terrestrial sediments or sands into deeplake settings. Rising topset-to-forest rollover trajectories with negative $T_{\mathrm{se}}$, in contrast, have low values of $A_{\mathrm{s}} / A_{\mathrm{d}}$ of 0 , lack aggradational topsets, and are fronted by sand-rich forests and bottomsets, with widespread occurrence of thicker and regionally extensive time-equivalent deep-lake sandy facies. They record near total bypass of sediment volumes to deep-lake floors, with very limited or no topset storage of sediment or sands. Topset-to-forest rollover trajectories 


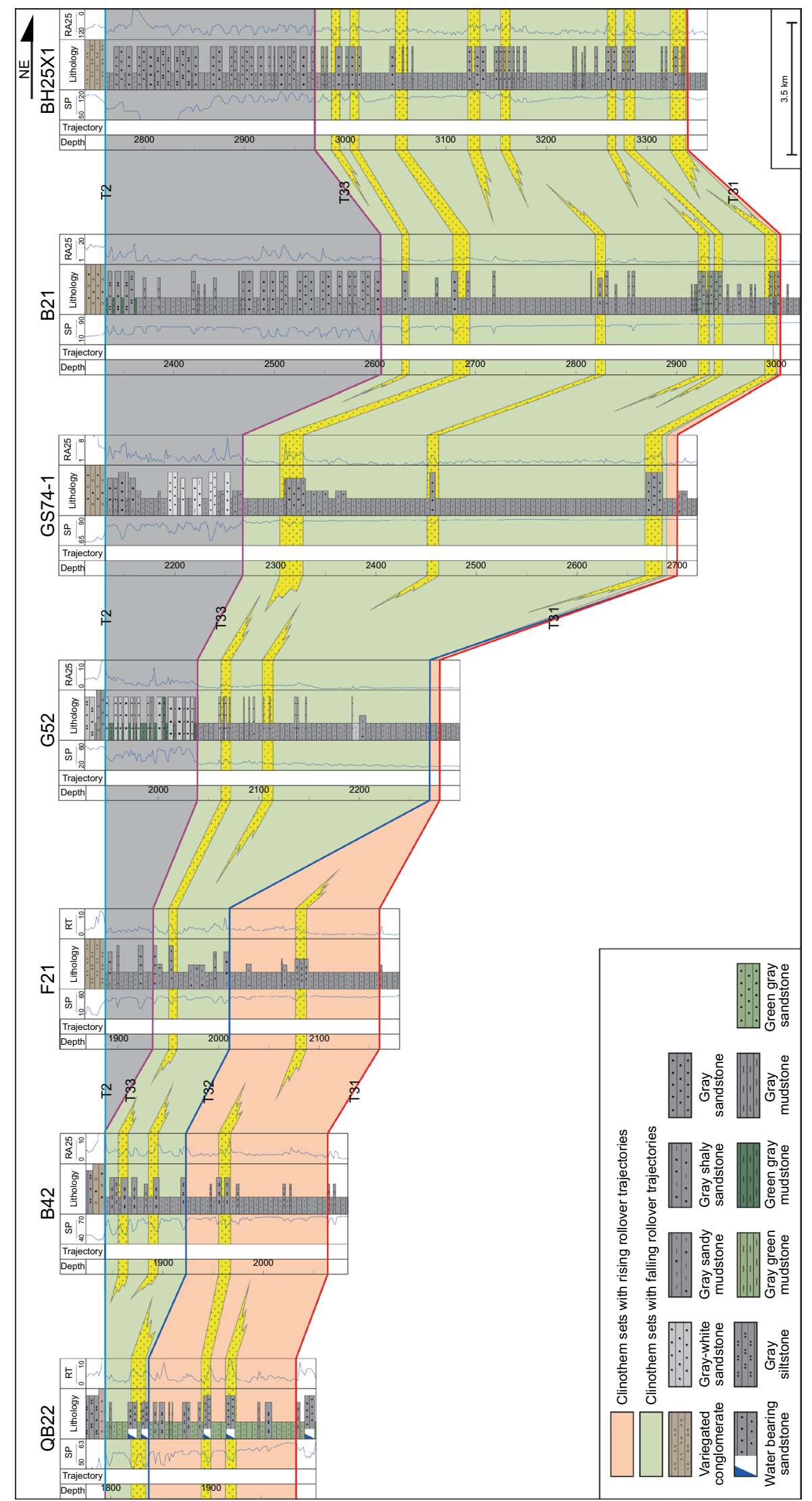


4Fig. 12 Log-stratigraphic correlation and composite section across wells QB22, B42, F21, G52, GS74-1, B21, and BH25X1 (see Fig. 2 for map-view locations of the shown cross section and wells). Note again that sandy deposits in front of slightly falling topset-to-forest rollover trajectories are much thicker and laterally more extensive than those in front of slightly rising topset-to-forest rollover trajectories

with their trajectory angles increasing linearly with amounts of deep-lake bottomset sandstones are, therefore, reliable predictors of sediment- and sand-volume partitioning into deep-lake areas, contributing to the development of a more predictive and dynamic sequence stratigraphy.

Acknowledgements We are grateful to PetroChina Dagang Oilfield Company for providing the subsurface data sets and for the permission to publish the results of this study. This research was jointly funded by the Science Foundation of China University of Petroleum, Beijing (Nos. 2462017YJRC061 and 2462020YXZZ020). We are grateful to journal editors for editorial handing and comments and to two anonymous reviewers for their constructive comments, all of which significantly improved the overall quality of this research.

Open Access This article is licensed under a Creative Commons Attribution 4.0 International License, which permits use, sharing, adaptation, distribution and reproduction in any medium or format, as long as you give appropriate credit to the original author(s) and the source, provide a link to the Creative Commons licence, and indicate if changes were made. The images or other third party material in this article are included in the article's Creative Commons licence, unless indicated otherwise in a credit line to the material. If material is not included in the article's Creative Commons licence and your intended use is not permitted by statutory regulation or exceeds the permitted use, you will need to obtain permission directly from the copyright holder. To view a copy of this licence, visit http://creativecommons.org/licenses/by/4.0/.

\section{References}

Catuneanu O, Abreu V, Bhattacharya JP, et al. Towards the standardization of sequence stratigraphy. Earth-Sci Rev. 2009;92:1-33. https://doi.org/10.1016/j.earscirev.2008.10.003.

Catuneanu O, Galloway WE, Kendall R, et al. Sequence stratigraphy: methodology and nomenclature. Newsl Stratigr. 2011;44:173245. https://doi.org/10.1127/0078-0421/2011/0011.

Cosgrove GIE, Hodgson DM, Poyatos-Moré M, et al. Filter or conveyor? Establishing relationships between clinoform rollover trajectory, sedimentary process regime, and grain character within intrashelf clinothems, offshore New Jersey, U.S.A. J Sediment Res. 2018;88:917-41. https://doi.org/10.2110/jsr.2018.44.

Feng Y, Jiang S, Hu S, et al. Sequence stratigraphy and importance of syndepositional structural slope-break for architecture of Paleogene syn-rift lacustrine strata, Bohai Bay Basin. E China Mar Petrol Geol. 2016;69:183-204. https://doi.org/10.1016/j.marpe tgeo.2015.10.013.

Gamberi F, Pellegrini C, Dalla Valle G, et al. Compound and hybrid clinothems of the last lowstand Mid-Adriatic Deep: processes, depositional environments, controls and implications for stratigraphic analysis of prograding systems. Basin Res. 2020;32:136377. https://doi.org/10.1111/bre.12417.

Gong C, Wang Y, Steel R, et al. Shelf-edge trajectories and stratal stacking patterns: their sequence-stratigraphic significance and relation to styles of deep-water sedimentation and amount of deepwater sandstone. AAPG Bull. 2015;99:1211-43. https://doi.org/ 10.1306/01311513229.

Gong C, Steel R, Wang Y, et al. Shelf-margin architecture variability and its role in sediment-budget partitioning into deep-water areas. Earth-sci Rev. 2016;154:72-101. https://doi.org/10.1016/j.earsc irev.2015.12.003.

Gong C, Qi K, Ma Y, et al. Tight coupling between the cyclicity of deep-water systems and rising-ten-flat shelf-edge pairs along the submarine segment of the Qiongdongnan sediment-routing systems. J Sediment Res. 2019a;89:956-75. https://doi.org/10.2110/ jsr.2019.47.

Gong C, Sztano O, Steel RJ, et al. Critical differences in sediment delivery and partitioning between marine and lacustrine basins: A comparison of marine and lacustrine aggradational to progradational clinothem pairs. GSA Bull. 2019b;131:766-81. https:// doi.org/10.1130/B32042.1.

Huang C, Wang H, Gao J, et al. Tectonic evolution and controlling on sequence filling pattern of Tertiary in Beitang Sag. J China Univ Petrol (Edn Nat Sci). 2008;32:7-13 (in Chinese).

Huang C, Wang H, Wu Y, et al. Genetic types and sequence stratigraphy models of Palaeogene slope break belts in Qikou Sag, Huanghua Depression, Bohai Bay Basin, Eastern China. Sediment Geol. 2012;261-262:65-75. https://doi.org/10.1016/j.sedgeo.2012.03. 005.

Helland-Hansen W, Martinsen OJ. Shoreline trajectories and sequences: description of variable depositional-dip scenarios. $\mathbf{J}$ Sediment Res. 1996;66:670-88. https://doi.org/10.1046/j.15251314.1996.03710.x.

Helland-Hansen W, Hampson GJ. Trajectory analysis: concepts and applications. Basin Res. 2009;21:454-83. https://doi.org/10. 1111/j.1365-2117.2009.00425.x.

Henriksen S, Hampson GJ, Helland-Hansen W, et al. Shelf edge and shoreline trajectories, a dynamic approach to stratigraphic analysis. Basin Res. 2009;21:445-53. https://doi.org/10.1111/j.13652117.2009.00432.x.

Jiang W, Liu S. Distribution and controlling factors of high-quality hydrocarbon source rock in sequential stratigraphic framework: Taking Paleogene system in Qikou Depression for instance. China Petrol Explor. 2015;20:51-8 (in Chinese).

Jiang W, Song Z, Zhou L, et al. Characteristics of stratal pressure structure in Qikou Sag, Bohai Bay Basin. J Jilin Univ (Earth Sci Edn). 2020;50:52-69 (in Chinese).

Jones GED, Hodgson DM, Flint SS. Contrast in the process response of stacked clinothems to the shelf-slope rollover. Geosphere. 2013;9:299-316. https://doi.org/10.1130/ges00796.1.

Laugier FJ, Plink-Björklund P. Defining the shelf edge and the threedimensional shelf edge to slope facies variability in shelf-edge deltas. Sedimentology. 2016;63:1280-320. https://doi.org/10. 1111/sed.12263.

Li M, Qi JF, Yang Q, et al. Cenozoic structure features of huanghua depression and its structure dynamics model. Acta Geoscientica Sinica. 2009;30:201-9 (in Chinese).

Liu J, Xian B, Ji Y, et al. Alternating of aggradation and progradation dominated clinothems and its implications for sediment delivery to deep lake: The Eocene Dongying Depression, Bohai Bay Basin, east China. Mar Petrol Geol. 2020;114:104197. https://doi.org/10. 1016/j.marpetgeo.2019.104197.

Patruno S, Helland-Hansen W. Clinoforms and clinoform systems: Review and dynamic classification scheme for shorelines, subaqueous deltas, shelf edges and continental margins. Earth-Sci Rev. 2018;185:202-33. https://doi.org/10.1016/j.earscirev.2018. 05.016.

Paumard V, Bourget J, Payenberg T, et al. Controls on shelf-margin architecture and sediment partitioning during a syn-rift to post-rift transition: Insights from the Barrow Group (Northern 
Carnarvon Basin, North West Shelf, Australia). Earth-Sci Rev. 2018;177:643-77. https://doi.org/10.1016/j.earscirev.2017.11. 026.

Paumard V, Bourget J, Payenberg T, et al. Controls on shelf-margin architecture and sediment partitioning during a syn-rift to postrift transition: Insights from the Barrow Group (Northern Carnarvon Basin, North West Shelf, Australia). J Sediment Res. 2020;90:104-30. https://doi.org/10.1016/j.earscirev.2017.11.026.

Pellegrini C, Maselli V, Gamberi F, et al. How to make a 350-m-thick lowstand systems tract in 17,000 years: The Late Pleistocene Po River (Italy) lowstand wedge. Geology. 2017;45:327-30. https:// doi.org/10.1130/G38848.1.

Pellegrini C, Patruno S, Helland-Hansen W, et al. Clinoforms and clinothems: Fundamental elements of basin infill. Basin Res. 2020;32:187-205. https://doi.org/10.1111/bre.12446.

Pendrel J. Seismic inversion: A critical tool in reservoir characterization. Scand Oil-Gas Mag. 2006;5:19-22.

Pyles DR, Syvitski JPM, Slatt RM. Defining the concept of stratigraphic grade and applying it to stratal (reservoir), architecture and evolution of the slope-to-basin profile: An outcrop perspective. Mar Petrol Geol. 2011;28:675-695. https://doi.org/10.1016/j. marpetgeo.2010.07.006.

Sztanó O, Szafián P, Magyar I, et al. Aggradation and progradation controlled clinothems and deep-water sand delivery model in the
Neogene Lake Pannon, Makó Trough, Pannonian Basin, SE Hungary. Glob Planet Change. 2013;103:149-67. https://doi.org/10. 1016/j.gloplacha.2012.05.026.

Trincardi F, Amorosi A, Bosman A, et al. Ephemeral rollover points and clinothem evolution in the modern Po Delta based on repeated bathymetric surveys. Basin Res. 2020;32:402-18. https://doi.org/ 10.1111/bre. 12426 .

Villamil T, Arango C, Weimer P, et al. Biostratigraphic techniques for analyzing benthic biofacies, stratigraphic condensation, and key surface identification, Pliocene and Pleistocene sediments, northern Green Canyon and Ewing Bank (offshore Lousiana), northern Gulf of Mexico. AAPG Bull. 1998;82:961-985.

Wang G, Qi J, Yue Y. Formation and evolution of the Cenozoic tectonics within and surrounding the Qikou Sag. Chin J Geol. 2003;38:230-40 (in Chinese).

Wild R, Flint SS, Hodgson DM. Stratigraphic evolution of the upper slope and shelf edge in the Karoo Basin, South Africa. Basin Res. 2009;21:502-27. https://doi.org/10.1111/j.1365-2117.2009. 00409.x.

Wu Y, Yang C, Wang H, et al. Integrated study of tectonics-sequence stratigraphy-sedimentology in the Qikou Sag and its application. Geotectonica et Metallogenia. 2010;34:451-60 (in Chinese). 